\title{
LICHEN DIVERSITY VALUE AND HEAVY METAL CONCENTRATIONS IN MOSSES AROUND THE LIGNITE POWER PLANTS 'KOSOVA'
}

\author{
BEHXHET, M. ${ }^{1}$ - HAJDARI, A. ${ }^{1}{ }^{*}$ - LÖKÖS, L. ${ }^{2}-$ KRASNIQI, Z. ${ }^{1}$ \\ ${ }^{I}$ Department of Biology, Faculty of Mathematical and Natural Science, University of Prishtina, \\ Mother Theresa Street, 10000, Prishtinë, Kosovo \\ ${ }^{2}$ Department of Botany, Hungarian Natural History Museum, Budapest, Hungary \\ *Corresponding author \\ e-mail: avhajdari@hotmail.com \\ (Received 26 $6^{\text {th }}$ April 2011; accepted 29 $9^{\text {th }}$ January 2013)
}

\begin{abstract}
Lichen and mosses are the most appropriate indicators for monitoring air pollution. To evaluate air quality in the Prishtina region, we determined lichen value diversity (LDV) and heavy metal concentrations in mosses at 20 sites around power plants 'Kosova A and B'. Twenty-three lichen species were recorded in the survey area. The lichen value diversity differed depending on the distance from the source of air pollution. Values ranged from 36.3 to 115.4, with the highest levels recorded in the cleanest area. This value decreased when moving towards the polluted areas. Concentrations of six heavy metals were measured in mosses (Brachythecium rutabulum (Hedw.) Schimp). Different concentrations of heavy metals in mosses were found during the investigation. The hot spots of heavy metals were associated with historical industrial activities, mining activities, and industrial centres. In addition, vehicle emissions near major roads were responsible for the high concentrations of trace elements in mosses in these areas. $\mathrm{Zn}$ was found in the highest concentration, and ranged from 56.5-136.6 $\mu \mathrm{g} \cdot \mathrm{g}^{-1}$.
\end{abstract}

Keywords: bioindicator, lichen value diversity, heavy metals, mosses

\section{Introduction}

Humans generate large amounts of pollutants that reduce air quality. The air pollutants that originate from anthropogenic sources include heavy metals, $\mathrm{CO}_{2}$, sulphur and nitrogen compounds (Pitcairn et al., 1995; Whelpdale et al., 1998; Pacyna et al., 2001). Air quality can be accurately estimated using lichens and mosses as bioindicators (Markert et al., 2003). The presence of air pollutants in a natural environment can cause changes in biochemical and physiological processes (Arb et al., 1990) and community structures. Lichens and mosses are cryptogams, which possess many properties that make them suitable for monitoring purposes: the cuticle is weakly developed, they do not have real roots, they are slow-growing and long-lived, they have an extremely broad distribution and they obtain nutrients from wet and dry deposition (Wolterbeek et al., 2003; Onianwa, 2001; Zechmeister et al., 2003). Lichens are highly sensitive to air pollution and have been identified as indicators of environmental quality, particularly air quality, since the 1800s (Nylander, 1866). Later, numerous of such studies have been conducted in industrial areas in a number of countries (Pejćinović and Hoxha, 1986, Sommerfeldt et al., 2001; Seaward, et al. 2004; Loppi, 2004; Bačkor, 2003; Munzi, 2007). In addition, mosses are highly efficient accumulators of many elements and are capable of accumulating persistent pollutants, such as heavy metals, in their natural environment (Rühling et al., 1994; Berg et al., 1996; Lepneva, 1987; Lippo et al., 2004). The aims of this study were to assess the air quality status by using lichens as 
bioindicators and the deposition pattern of selected heavy metals by using mosses as bioaccumulators around lignite power plants located in the Prishtina region.

\section{Materials and methods}

\section{Study area}

The study area was located northwest of Kosovo and contained an area of about 200 $\mathrm{km}^{2}$ around power plants 'Kosova A and B'. The study region is rich with natural resources, and there are large reserves of coal (lignite) and many mines (Stanterg mine $(\mathrm{Pb}, \mathrm{Zn})$; Magure mine ( $\mathrm{Mg}, \mathrm{Fe}, \mathrm{Ni})$; Hajvalia mine ( $\mathrm{Pb}, \mathrm{Zn})$; Gllogoc mine (Fe, Ni)). The economy of the Prishtina region has been based mainly on the exploitation of these natural resources, such as electricity production (power plants that use coal as fuel), coal and mineral exploitation, and smelters (Ferronickel smelter). With the exception of Mitrovica, which was one of the largest industrial areas of the former Yugoslavia, the Prishtina region is considered to be the most polluted area in Kosovo. A major source of pollution in this region is the industrial complex in Obilic. This industrial complex consists of facilities that produce hazardous emissions in the area of Prishtina and beyond. The main sources of emissions from the industrial complex include open mining for lignite used as fuel in power plants, and lignite drying and heating plants. In the past, gasification and fertilizer plants were also sources of pollution, but these were permanently closed in 1988-89. With a total capacity of 1,478 MW (Gjendja e Mjedisit Raport 2008), the power plants 'Kosova A and B' are the major sources of pollution due to emissions of sulphur dioxide, nitrogen oxides, dust, fly ash, smoke, radioactive soleplates and carbon gases. 'Kosova B' discharges approximately $260 \mathrm{~g} / \mathrm{s} \mathrm{SO}$, $556 \mathrm{~g} / \mathrm{s}$ $N O_{x}$ and $376 \mathrm{~g} / \mathrm{s}$ dust (Varjoranta and Pietarila, 2005). One unit of 'Kosova B,' with a capacity of $200 \mathrm{MW}$, emits about 25 tons of dust and ash per hour, which is 74 times more than the European standards (WHO, 2002). Currently, there are plans to build a new power plant, 'Kosova C,' in the same location. Chemical analysis of the dust particles which originated from the power plant contains different chemical elements including radio-nucleotides $\mathrm{Pb}^{214}, \mathrm{Ti}^{218}, \mathrm{Cs} 137, \mathrm{U}^{235}$ (Adrović et al., 1996) and toxic compounds as $\mathrm{NO}_{x}, \mathrm{SO}_{2}, \mathrm{As}, \mathrm{Pb}, \mathrm{Cd}, \mathrm{Ni}, \mathrm{Cr}, \mathrm{Co}$, etc., which have negative impacts on living organisms. The annual average temperature in the study region is $10.9{ }^{\circ} \mathrm{C}$, the average annual rainfall is $638.3 \mathrm{~mm}$ and the annual average of insulation is 2,140 hours per year. The wind predominantly blows from north and northeast with an average velocity of $3 \mathrm{~m} / \mathrm{s}$ (data from the Kosovo Meteorological Institute).

\section{LDV determination}

The standardized EU lichen recording method (Asta et al., 2002) was used to determine the lichen value diversity. The sampling units were selected in different sites around power plants to investigate the effects of environmental stress on lichens. This sampling strategy was designed to capture variation of the epiphytic lichen value diversity. Most of the sites were concentrated in southeast, south and south west of the power plants corresponding to the wind direction, where most of the changes were expected (Table 1). Within the study region, 20 sampling sites were randomly selected. Sampling was conducted exclusively in trees outside the woodlands. The size of the sample unit was 0.5 X $0.5 \mathrm{~km}$. All sites were geo-referenced using GPS (Garmine-gekos 201). 
Sampling units were selected based on the presence of suitable trees and no road disturbance. In six sampling units LDV was determined in oak trees, and in fourteen sampling units LDV was determined in the popular (Populus) species. Only trees of a single species were selected within a survey unit to determine LDV. The selected sampling units were divided into four equal quadrants, and within each of these quadrants, three tree trunks were selected according to the conditions listed above (Asta et al., 2002). To record the presence and frequency of each lichen species, we used a laddered quadrate comprising five quadrate squares $(10 \mathrm{~cm} \times 10 \mathrm{~cm})$. The lowest quadrate began at $100 \mathrm{~cm}$ above ground level on each aspect $(\mathrm{N}, \mathrm{S}, \mathrm{E}, \mathrm{W})$ of each tree. All lichen species present within the quadrates were recorded. Lichen value diversity was calculated for each sampling unit.

The sum of the frequencies of all lichen species for each aspect on each tree (i) was calculated in each sampling unit. For each tree there were four sums of frequencies (tree i: SFiN, SFiE, SFiS, SFiW). Then the arithmetic mean of the sum of frequencies (MSF) for the sampling unit $\mathrm{j}$ was calculated using the following formula:

$$
\mathrm{MSFNj}=(\mathrm{SF} 1 \mathrm{Nj}+\mathrm{SF} 2 \mathrm{Nj}+\mathrm{SF} 3 \mathrm{Nj}+\mathrm{SF} 4 \mathrm{Nj}+\ldots . .+\mathrm{SFnNj}) / \mathrm{n}
$$

Where:

MSFN $j$ is the mean of the sum of the frequencies of all trees of unit $j$ for each aspect (e.g. North)

$\mathrm{SFiNj}$ is the sum of the frequencies of all species recorded for each aspect (e.g. North) of tree in unit $j$

$\mathrm{n}$ is the number of surveyed trees with a given aspect in unit $\mathrm{j}$

The lichen value diversity of the sampling unit $\mathrm{j}(\mathrm{LDVj})$ was calculated as the sum of the MSF-s of all aspects:

$$
\mathrm{LDVj}=(\mathrm{MSFNj}+\mathrm{MSFEj}+\mathrm{MSFSj}+\mathrm{MSFWj})
$$

\section{Heavy metal determination}

In the same localities where we determined the LDV, we also collected mosses to measure the concentration of heavy metals. The moss samples were collected in sites that were located at least $300 \mathrm{~m}$ from the main roads, at least $100 \mathrm{~m}$ from any road or single house and $3 \mathrm{~m}$ away from the nearest tree. On each sampling site, 3 subsamples were taken within an area of $50 \mathrm{~m} \times 50 \mathrm{~m}$. Brachythecium rutabulum (Hedw.) Schimp was used to determine the concentration of heavy metals, as this species were present in the study area. All dead materials were cleaned from the samples and only the portion with green and green-brown mosses was included. The samples were dried to a constant weight at $40{ }^{\circ} \mathrm{C}$. After being cleaned and dried, one gram of moss for each sample was burned in the temperature $450{ }^{\circ} \mathrm{C}$ for three hours. Heavy metal concentrations $(\mathrm{Cd}, \mathrm{Pb}, \mathrm{Cu}, \mathrm{Zn}, \mathrm{CO}$ and $\mathrm{Ni})$ were determined by standard methods using AAS - atomic absorption spectroscopy (UNICAM 929 spectrometer) (Mendil et al., 2009). The concentrations of heavy metals were expressed in $\mu \mathrm{g} / \mathrm{g}$ dry weight. 


\section{Data analysis}

Data analysis was performed using SPSS 15. Lichen value diversities were used for multivariate analysis (Cluster Analysis) to cluster the sites based on the average linkage (Between Groups).

\section{Species identification}

Murati M. (1992, 1993) and Wirth (1995) were consulted for lichen determination. The moss species Brachythecium rutabulum (Hedw.) Schimp was identified by Beata Papp.

\section{Results and discussion}

\section{Floristic data}

During the investigation to determine the lichen value diversity around power plants 'Kosova A and B' we recorded 23 epiphytic lichen species, which are listed below. The majority were foliose species (11), 7 were crustose species, and 5 were fruticose species. The genera with the highest number of species were Candelariella, Lecanora, Melanelia, Phaeophyscia Physcia and Ramalina. Other genera had only one species per genera.

List of lichen species found around power plants.

1. Anaptychia ciliaris (L.) Körb.

2. Arthrosporum populorum A. Massal.

3. Caloplaca holocarpa (Hoffm.) A. E. Wade

4. Candelariella aurella (Hoffm.) Zahlbr.

5. Candelariella cf. reflexa (Nyl.) Lettau

6. Evernia prunastri (L.) Ach.

7. Flavoparmelia caperata (L.) Hale

8. Lecanora carpinea (L.) Vain.

9. Lecanora subrugosa

10. Melanelia exasperata (De Not.) Essl.

11. Melanelia glabra (Schaer.) Essl.

12. Parmelia sulcata Taylor

13. Parmelina tiliacea (Hoffm.) Hale

14. Phaeophyscia nigricans (Flörke)

15. Phaeophyscia orbicularis (Neck.) Moberg

16. Physcia adscendens

17. Physcia stellaris (L.) Nyl.

18. Pleurosticta acetabulum (Neck.) Elix \& Lumbsch

19. Pseudevernia furfuracea (L.) Zopf

20. Ramalina fastigiata (Pers.) Ach.

21. Ramalina fraxinea (L.) Ach.

22. Rinodina pyrina (Ach.) Arnold

23. Xanthoria parietina (L.) Th. F 
Table 1. List of the main characteristics of the sample sites. Each locality was identified by number, name, GPS coordinate, tree species, number of lichen species, number of lichen species from above list and lichen diversity values

\begin{tabular}{|c|c|c|c|c|c|c|c|c|}
\hline No. & Localities & Longitude & Latitude & $\begin{array}{l}\text { Orien- } \\
\text { tation }\end{array}$ & $\begin{array}{l}\text { Plant } \\
\text { species }\end{array}$ & $\begin{array}{l}\text { Nr. of } \\
\text { species }\end{array}$ & $\begin{array}{c}\text { Lichen sp. from } \\
\text { above list of } \\
\text { lichens. }\end{array}$ & LDV \\
\hline 1 & Obiliq & $21^{\circ} 04^{\prime} 1.8^{\prime \prime}$ & $42^{\circ} 41^{\prime} 6.9^{\prime \prime}$ & $\begin{array}{c}\text { CENTE } \\
\text { R }\end{array}$ & Populous & 3 & $4,15,23$ & 41.6 \\
\hline 2 & Shkabaj & $21^{\circ} 06 ' 24.5^{\prime \prime}$ & $42^{\circ} 39^{\prime} 59.0^{\prime \prime}$ & E & Populous & 5 & $4,9,14,15,23$ & 49.4 \\
\hline 3 & Dragodan & $21^{\circ} 09^{\prime} 5.7^{\prime \prime}$ & $42^{\circ} 40^{\prime} 11.4 "$ & E & Populous & 7 & $\begin{array}{l}4,8,15,17,18 \\
21,23\end{array}$ & 58.7 \\
\hline 4 & Taukbashqe & $21^{\circ} 10^{\prime} 55.6^{\prime \prime}$ & $42^{\circ} 39^{\prime} 55.1^{\prime \prime}$ & E & Populous & 5 & $4,8,15,21,23$ & 64.7 \\
\hline 5 & Mramor & $21^{\circ} 17 ' 59.1^{\prime \prime}$ & 42³9'7.7" & $\mathrm{E}$ & Quercus & 8 & $\begin{array}{l}4,8,10,12,15, \\
16,21,23,\end{array}$ & 96.2 \\
\hline 6 & Lagja e spitalit & $21^{\circ} 10^{\prime} 1.4^{\prime \prime}$ & $42^{\circ} 38^{\prime} 43.6^{\prime \prime}$ & $\mathrm{SE}$ & Populous & 5 & $8,14,5,16,23$ & 59.2 \\
\hline 7 & Graqanic & $21^{\circ} 12^{\prime} 43.4^{\prime \prime}$ & $42^{\circ} 36^{\prime} 6.1^{\prime \prime}$ & SE & Populous & 5 & $8,14,15,16,23$ & 78.1 \\
\hline 8 & Slivovë & $21^{\circ} 20^{\prime} 28.1^{\prime \prime}$ & $42^{\circ} 35^{\prime} 15.5^{\prime \prime}$ & SE & Quercus & 15 & $\begin{array}{l}1,2,4,8,10,11, \\
12,15,16,17, \\
18,19,20,21,23\end{array}$ & 115.4 \\
\hline 9 & Prelez & $21^{\circ} 10^{\prime} 31.4^{\prime \prime}$ & $42^{\circ} 27^{\prime} 36.6^{\prime \prime}$ & S & Populous & 3 & $8,15,23$ & 75.5 \\
\hline 10 & Ferizaj & $21^{\circ} 11^{\prime} 1.3^{\prime \prime}$ & $42^{\circ} 22^{\prime} 6.5^{\prime \prime}$ & $\mathrm{S}$ & Populous & 4 & 15,23 & 56.8 \\
\hline 11 & Lipjan & $21^{\circ} 06^{\prime} 42.2^{\prime \prime}$ & $42^{\circ} 30^{\prime} 55.1^{\prime \prime}$ & SSW & Populous & 5 & $6,8,9,15,21,23$ & 70.0 \\
\hline 12 & Magure & $21^{\circ} 00^{\prime} 49.3^{\prime \prime}$ & $42^{\circ} 32^{\prime} 37.7^{\prime \prime}$ & SWW & Quercus & 4 & $4,14,15,23$ & 79.2 \\
\hline 13 & Kroi i mbaretit & $20^{\circ} 56^{\prime} 54.0^{\prime \prime}$ & $42^{\circ} 36^{\prime} 8.06^{\prime \prime}$ & SW & Populous & 6 & $4,5,8,15,21,23$ & 97.4 \\
\hline 14 & Sllatin & $21^{\circ} 00^{\prime} 8.3^{\prime \prime}$ & $42^{\circ} 35^{\prime} 44.8^{\prime \prime}$ & SWW & Quercus & 4 & $4,14,15,23$ & 77.6 \\
\hline 15 & Lismir & $21^{\circ} 04^{\prime} 19.5^{\prime \prime}$ & $42^{\circ} 40^{\prime} 6.5^{\prime \prime}$ & W & Populous & 3 & $4,15,23$ & 36.2 \\
\hline 16 & Grabovc & $20^{\circ} 59^{\prime 29.4 "}$ & $42^{\circ} 39^{\prime} 36.5^{\prime \prime}$ & W & Quercus & 8 & $\begin{array}{l}4,11,12,15,18 \\
19,21,22,23\end{array}$ & 64.6 \\
\hline 17 & Drenas & $20^{\circ} 54^{\prime} 14.8^{\prime \prime}$ & $42^{\circ} 39^{\prime} 36.4^{\prime \prime}$ & W & Quercus & 9 & $\begin{array}{l}4,5,7,8,11, \\
13,15,16,18,23\end{array}$ & 93.1 \\
\hline 18 & Vushtrri & $20^{\circ} 59^{\prime} 46.0^{\prime \prime}$ & $42^{\circ} 47^{\prime} 59.7^{\prime \prime}$ & NW & & 4 & $9,14,15,23$ & 76.8 \\
\hline 19 & Drenove & $21^{\circ} 03^{\prime} 38.7^{\prime \prime}$ & $42^{\circ} 41^{\prime} 35.3^{\prime \prime}$ & $\mathrm{N}$ & dlous & 2 & 15,23 & 72.0 \\
\hline 20 & Bardhosh & $21^{\circ} 08^{\prime} 59.1^{\prime \prime}$ & $42^{\circ} 42^{\prime} 58.3^{\prime \prime}$ & NE & Populous & 5 & $3,4,8,15,16,23$ & 70.5 \\
\hline
\end{tabular}

\section{Lichen diversity}

The lichen value diversity results and characteristics of the study sites are shown in Table 1. Lichen value diversity was used to estimate the air quality, which ranged from 36.3 to 115.4 . Lichen value diversity was compared with the LDV interpretation scale (Asta et. al., 2002), and our results are distinguished in six classes (Table 2).

Table 2. Interpretation scale of lichen value diversity ranges of sampling units and the corresponding interpretation (Asta et al. 2002)

\begin{tabular}{c|c|c|c}
\hline $\begin{array}{c}\text { LDV } \\
\text { interpretation } \\
\text { class }\end{array}$ & $\begin{array}{c}\text { LDV interpretation } \\
\text { subclass }\end{array}$ & $\begin{array}{c}\text { Lichen value } \\
\text { diversity }\end{array}$ & location numbers (see Table 1) \\
\hline 1. Very high & very high & $>81$ & $5,8,13,17$ \\
2. High & high to very high & $71-80$ & $7,9,12,14,18,19$ \\
3. Moderate & high & $61-70$ & $4,11,16.20$ \\
& moderate to high & $51-60$ & $3,6,10$, \\
4. Low & moderate & $41-50$ & 1,2, \\
& low to moderate & $31-40$ & 15 \\
5. Very low & low & $21-30$ & - \\
& very low & $11-20$ & - \\
\hline
\end{tabular}


The LDV of different sites ranges from low to very high lichen value diversities, most sites range in subclass from high to very high LDV (Table 2). The highest number of lichen species was found in the cleanest sites. In polluted areas, the number of lichen species was very low (Table 1). Candelariella aurella, Lecanora carpinea, Phaeophyscia orbicularis and Xanthoria parietina were found in the majority of the sites, as they are toxitolerant species. Species with the lowest frequencies were Anaptychia ciliaris, Flavoparmelia caperata, Parmelina tiliacea, and Pseudevernia furfuracea, which are sensitive to air pollution.

A hierarchical cluster analysis was performed to group the various parameters (LDV) according to their values. Based on the average linkage (between groups), the results were grouped into six different groups, which were displayed in the dendrogram (Fig. 1). The groups in the dendrogram are quite similarly grouped, with groups interpolated according Asta et al.(2002) (Table 2).

Group A. Includes only one site, Slivovë, which is located in the SE area, is farther from power plants, and is characterized with the highest value of lichen diversity.

Group B. Includes sites that have high lichen value diversity $(93.1-97.4)$, but this value was lower than in sites grouped into Group A.

Group C. Includes sites Obiliq and Lismir, which are the closest sites to the power plants and, consequently, are more polluted areas. The LDV fluctuate from 36.2 - 41.6.

Group D. Dragodan, Lagja e spitalit, Ferizaj, Shkabaj were included in this group. The LDV of these sites ranged from 49.4 to 59.2. These sites are characterized with higher LDV than sites grouped in group C.

Group E. Includes five sites that have a LDV from 75.5 to 79.3. They have higher lichen value diversity than sites in group $\mathrm{D}$, and lower than sites in group B

Group F. Includes sites with lichen value diversity fluctuate from 64.7 to 72.0 .

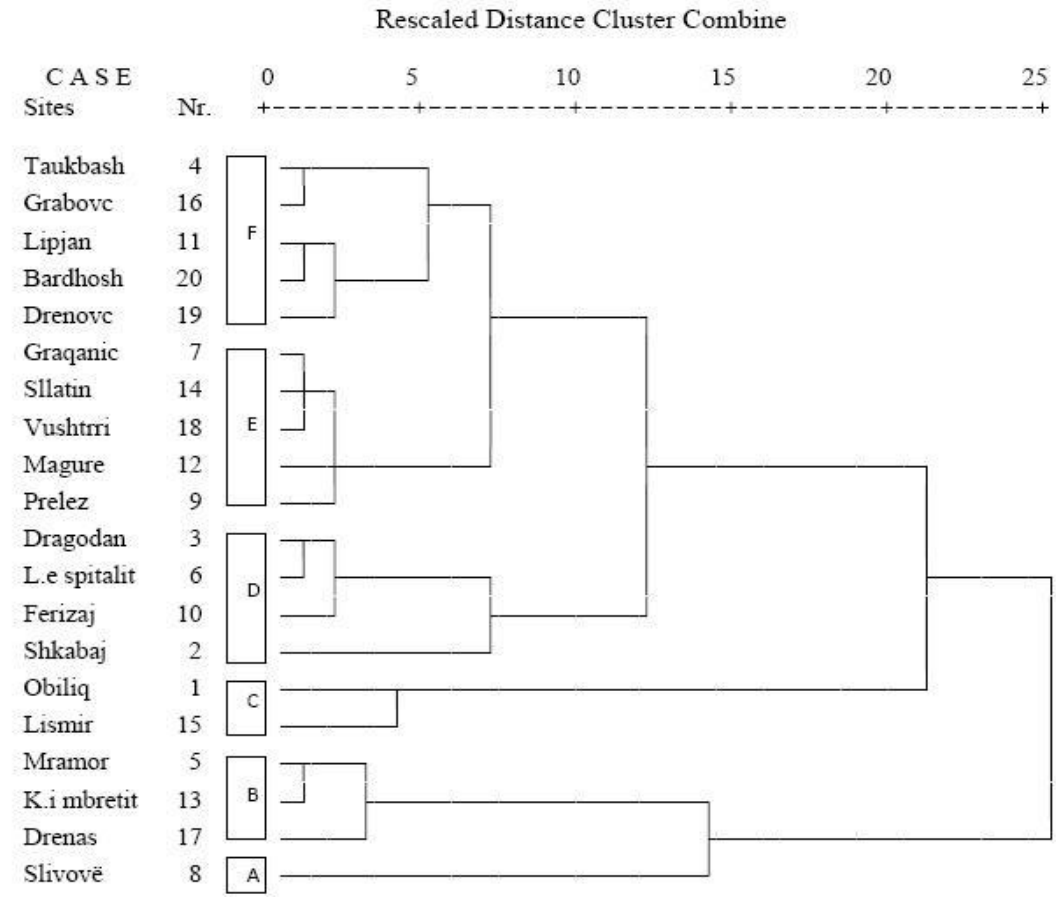

Figure 1. Cluster analysis dendrogram. Cluster analysis of sites around power plants 'Kosova $A$ and $B$ ' based on the average linkage (Between Groups) of lichen values diversity 
In most cases, lichen value diversity was low near the source of pollution and fell into the 'Low moderate and moderate' LDV class (Table 2). This value increased with increasing distance from the source of pollution, and fell into the higher LDV class. Higher LDV was recorded east and west of the source of pollution where localities had high vegetation richness. The lowest values were recorded near the power plants, main roads and mines which are characterized by higher levels of air pollution and poorness of vegetation. The influence of distance was found south of the power plant areas, which pollution dispersion by the wind, the presence of the main road, the lack of vegetation, and the presence of residents may have also played a role. Taking into consideration the presence of lichens and LDV, the air in the Prishtina region had a higher quality than the air around the Mitrovica region, which was the main industrial area in Kosovo and in former Yugoslavia. In the Mitrovica region, the air quality was very poor. In vast areas, there was an absolute 'lichen desert' (Pejqinoviq and Hoxha, 1986, Pejqinoviq and Hoxha, 1988), which still exists (Borgna, 2009), even though the industrial activities decreased rapidly after 1990 and nearly stopped completely in 2001.

\section{Heavy metal concentration}

Table 3 shows the minimum, maximum, median and average values for six trace element concentrations $(\mathrm{Zn}, \mathrm{Pb}, \mathrm{Cu}, \mathrm{Co}, \mathrm{Ni}, \mathrm{Cd})$ measured in moss samples from different sites. The concentration of trace metals differed depending on the distance from pollution sources. The hot spots were associated with historical industrial activities, mining activities, and industrial centres. Source pollution per locality is given in Table 3, and along the major roads, vehicle emission is responsible for the high concentrations of trace elements in the mosses. Zinc had the highest concentration and ranged from $56.5-136.6 \mu \mathrm{g} . \mathrm{g}^{-1}$. This value decreased as follows: $\mathrm{Pb}: 2.10-66.3 \mu \mathrm{g}^{-\mathrm{g}^{-1}}$;

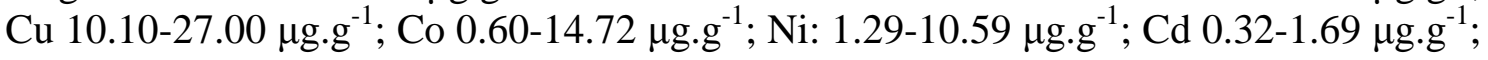
(Table 3).

A wide range was observed for $\mathrm{Zn}$ concentrations in the survey region, with values from 56.50 to $136.47 \mu \mathrm{g} \cdot \mathrm{g}^{-1}$ (median $=81.1 \mu \mathrm{g} \cdot \mathrm{g}^{-1}$ Table 3 ). The highest median zinc concentration was found near the Hajvalia mine, with a median value $136.47 \mu \mathrm{g} . \mathrm{g}^{-1}$. High levels of zinc were found near mines, power plants, and main roads. The concentrations of $\mathrm{Zn}$ significantly exceeded the average concentration of $\mathrm{Zn}$ in mosses from the Balkan region countries (Bulgaria $27.9 \mu \mathrm{g} . \mathrm{g}^{-1}$; Serbia $29.0 \mu \mathrm{g} . \mathrm{g}^{-1}$; Croatia 29.0 $\mu \mathrm{g} . \mathrm{g}^{-1}$; Slovenia $38.6 \mu \mathrm{g} . \mathrm{g}^{-1}$; FYR of Macedonia 35.6 $\mu \mathrm{g} . \mathrm{g}^{-1}$ (Harmens et al., 2008) and Bosnia and Herzegovina $23.8 \mu \mathrm{g} . \mathrm{g}^{-} 1$, (ESC, 2003)).

The $\mathrm{Pb}$ concentrations in the Prishtina region had a wide range $\left(2.10\right.$ to $\left.66.3 \mu \mathrm{g} . \mathrm{g}^{-1}\right)$ in mosses sampled, with a median value of $19.2 \mu \mathrm{g} \cdot \mathrm{g}^{-1}$. The concentration of $\mathrm{Pb}$ was higher compared to countries in the Balkan (Bulgaria $14.8 \mu \mathrm{g} . \mathrm{g}^{-1}$; Croatia $2.57 \mu \mathrm{g} . \mathrm{g}^{-1}$; FYR of Macedonia $7.62 \mu \mathrm{g} . \mathrm{g}^{-1}$; Serbia $16.7 \mu \mathrm{g} . \mathrm{g}^{-1}$; Slovenia $10.1 \mu \mathrm{g} . \mathrm{g}^{-1}$ Harmens et al., 2008). $\mathrm{Pb}$ content was also higher compared to its concentration in vegetables from the Mitrovica region (pepper up to $4.86 \mu \mathrm{g} . \mathrm{g}^{-1}$ and cabbage up to $7.56 \mu \mathrm{g} . \mathrm{g}^{-1}$ Borga, 2009).

Copper concentrations in mosses varied between 10.1 to $27.0 \mu \mathrm{g} \cdot \mathrm{g}^{-1}$, with a median value $17.6 \mu \mathrm{g} \cdot \mathrm{g}^{-1}$ (Table 3). Compared with other countries in the Balkan region, the $\mathrm{Cu}$ median value in mosses from the Prishtina region was higher than Serbia $11.1 \mu \mathrm{g} . \mathrm{g}^{-1}$, Croatia $7.54 \mu \mathrm{g} . \mathrm{g}^{-1}$, FYR of Macedonia $6.65 \mu \mathrm{g} . \mathrm{g}^{-1}$, Slovenia $8.17 \mu \mathrm{g} . \mathrm{g}^{-1}$, Bulgaria 10.7 $\mu \mathrm{g} . \mathrm{g}^{-1}$ (Harmens et al., 2008). 
Cadmium concentrations ranged from 0.32 to $1.69 \mu \mathrm{g} . \mathrm{g}^{-1}$, with a median value 0.49 $\mu \mathrm{g} . \mathrm{g}^{-1}$ (Table 3). The content of cadmium had a higher concentration than other Balkan countries (Serbia $0.26 \mu \mathrm{g} . \mathrm{g}^{-1}$; Croatia $0.28 \mu \mathrm{g} . \mathrm{g}^{-1}$; Bulgaria $0.31 \mu \mathrm{g} . \mathrm{g}^{-1}$; Slovenia 0.33

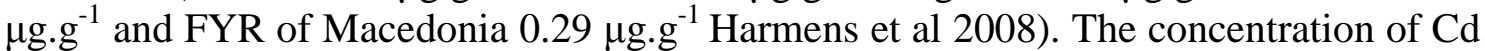
in mosses was also lower than in maize (up to $\left.1.67 \mu \mathrm{g} . \mathrm{g}^{-1}\right)$, Boletus edulis $\left(16.0 \mu \mathrm{g}_{\mathrm{g}} \mathrm{g}^{-1}\right.$ ), from the Mitrovica region, which is located near the Prishtina region (Borga et al., 2009).

The Co concentration in mosses ranged from 0,60 to $14.72 \mu \mathrm{g} \cdot \mathrm{g}^{-1}$ with a median value of $6.7 \mu \mathrm{g} \cdot \mathrm{g}^{-1}$.

$\mathrm{Ni}$ contents in mosses from the Prishtina region also showed wide ranges from 1.29 to $10.59 \mu \mathrm{g} . \mathrm{g}^{-1}$ with a median value $3.90 \mu \mathrm{g} . \mathrm{g}^{-1}$ (Table 3 ). The median value of $\mathrm{Ni}$ concentration in the Prishtina region was higher than in other countries in the Balkan region (Croatia $2.68 \mu \mathrm{g} . \mathrm{g}^{-1}$ Slovenia $2.75 \mu \mathrm{g} . \mathrm{g}^{-1}$ Bulgaria $2.99 \mu \mathrm{g} . \mathrm{g}^{-1}$ Harmens et al 2008), but lower than in Bosnia and Herzegovina $4.85 \mu \mathrm{g} . \mathrm{g}^{-1}$, Serbia $4.43 \mu \mathrm{g} . \mathrm{g}^{-1}$, FRY of Macedonia $5.82 \mu \mathrm{g} . \mathrm{g}^{-1}$ Harmens et al., 2008.

Table 3. Concentrations of heavy metals ( $\mu \mathrm{g} / \mathrm{g}$ dry weight) measured in moss samples collected in different locations around power plants 'Kosova'

\begin{tabular}{|c|c|c|c|c|c|c|c|c|}
\hline Localities & $\begin{array}{c}\text { Source of air } \\
\text { pollution }\end{array}$ & LDV & Cd & $\mathbf{P b}$ & $\mathrm{Cu}$ & $\mathbf{Z n}$ & Co & $\mathbf{N i}$ \\
\hline Lisnir & Power plant & 36.2 & 0.33 & 2.10 & 16.2 & 58.16 & 1.06 & 2.15 \\
\hline Grabovc & $\begin{array}{l}\text { Power plant. Coal } \\
\text { mine }\end{array}$ & 64.6 & 0.63 & 21.12 & 26.96 & 69.67 & 0.60 & 3.29 \\
\hline Drenovc & Traffic & 72.0 & 0.46 & 26.80 & 22.40 & 84.00 & 6.45 & 10.59 \\
\hline Vushtrri & Stanterg mine & 76.8 & 1.23 & 42.93 & 17.60 & 99.67 & 4.32 & 5.37 \\
\hline Obiliq & Power plant & 41.6 & 0.62 & 19.00 & 15.40 & 66.33 & 7.60 & 4.50 \\
\hline Shkabaj & Power plant & 49.4 & 0.41 & 5.87 & 15.67 & 64.56 & 1.19 & 6.87 \\
\hline Sllatin & $\begin{array}{l}\text { Ferronickel } \\
\text { factory, airport }\end{array}$ & 77.6 & 0.66 & 9.25 & 10.45 & 56.50 & 11.5 & 6.87 \\
\hline Magure & Magure mine & 79.2 & 1.69 & 18.00 & 10.10 & 89.00 & 9.36 & 10.46 \\
\hline Lipjan & $\begin{array}{l}\text { Power plant, } \\
\text { traffic }\end{array}$ & 70.0 & 0.46 & 30.00 & 20.20 & 94.67 & 2.13 & 3.06 \\
\hline Kroi i mbaretit & $\begin{array}{l}\text { Ferronickel } \\
\text { factory, traffic }\end{array}$ & 97.4 & 0.49 & 19.20 & 12.33 & 76.67 & 14.07 & 5.89 \\
\hline Drenas & $\begin{array}{l}\text { Ferronickel } \\
\text { factory }\end{array}$ & 93.1 & 0.55 & 44.20 & 17.10 & 84.33 & 8.53 & 3.92 \\
\hline Dragodan & $\begin{array}{l}\text { Power plant, } \\
\text { traffic }\end{array}$ & 58.7 & 0.35 & 21.73 & 19.73 & 69.89 & 8.61 & 4.12 \\
\hline Taukbashqe & Traffic & 64.7 & 0.45 & 19.20 & 27.00 & 90.33 & 7.53 & 5.50 \\
\hline Graqanic & Hajvalia mine & 78.1 & 0.40 & 66.36 & 25.04 & 136.47 & 2.59 & 4.19 \\
\hline Slivovë & Traffic & 115.4 & 0.86 & 13.40 & 16.20 & 81.17 & 1.20 & 1.94 \\
\hline Mramor & Hajvalia mine & 96.2 & 0.76 & 19.60 & 25.50 & 73.00 & 14.72 & 1.28 \\
\hline Prelez & Traffic & 75.5 & 0.34 & 20.50 & 18.00 & 84.22 & 3.55 & 3.11 \\
\hline Bardhosh & Traffic & 70.5 & 0.32 & 10.33 & 21.07 & 83.00 & 4.87 & 3.11 \\
\hline Lagja e spitalit & Traffic & 59.2 & 0.34 & 17.90 & 17.87 & 80.22 & 6.73 & 3.71 \\
\hline Ferizaj & Traffic & 56.8 & 0.34 & 14.00 & 14.80 & 65.33 & 8.77 & 1.55 \\
\hline & Mean & 76.6 & 0.61 & 23.1 & 18.4 & 81.8 & 6.5 & 4.5 \\
\hline & Median & 75.5 & 0.49 & 19.2 & 17.6 & 81.1 & 6.7 & 3.9 \\
\hline & Minimum & 36.2 & 0.32 & 2.10 & 10.10 & 56.50 & 0.60 & 1.29 \\
\hline & Maximum & 115.4 & 1.69 & 66.36 & 27.00 & 136.47 & 14.72 & 10.59 \\
\hline
\end{tabular}




\section{Conclusion}

Taking into consideration the lichen value diversity and heavy metal concentration in mosses from Prishtina region, we can conclude that the lichen value diversity was influenced by different environmental factors acting in the same territory. Near the source of pollution, the lowest levels of LDV are found. There was a progressive increase of LDV with increasing distance from the source of pollution. Heavy metal concentrations in our moss samples varied greatly from the distance of sites from the source of pollution. High concentrations of heavy elements, such as $\mathrm{Pb}, \mathrm{Cd}, \mathrm{Co}, \mathrm{Ni}, \mathrm{Zn}$ and $\mathrm{Cu}$, were found in the Prishtina region, which is connected with the former industrial activity of heavy metal pollution (e.g. mines, mine disposal sites, power plants, etc.). In all cases, a non-significant correlation was found between LDV and heavy metal, which suggests that other compounds like are $\mathrm{NO}_{\mathrm{x}}$ and $\mathrm{SO}_{2}$ seem to be responsible for the low level of LDV in these polluted areas. Further studies are required in the Prishtina region to determine what is contributing to the low levels of LDV.

Acknowledgements. For the identification of the moss species, the authors are grateful to Beata Papp, Department of Botany, Hungarian Natural History Museum, Budapest, Hungary.

\section{REFERENCES}

[1] Adrović, F., Popović, R., Ninković, M. (1996): The gama doze rates of radiation in the air and closer and further surrounding of the Kosovian Coal Power Plants. - Univ. Thought. Nat. sci. 87-90.

[2] Arb, C.V., Muller, C., Amman, K., Brunold, C. (1990): Lichen physiology and air pollution. - New Phytologyst 115: 431-437.

[3] Asta. J., Erhardt, W., Fornasier, F., Kirschbaum, U., Nimis, P. (2002): Mapping lichen diversity as an indicator of environmental quality. - NATO Science Series. IV. 7: 273279.

[4] Bačkor, M. (2003): Monitoring of Air Pollution in Košice (Eastern Slovakia) Using Lichens. - Polish Journal of Environmental Studies 12: 141-150.

[5] Berg, T., Pedersen, U., Steinnes, E. (1996): Environmental indicators for longrange atmospheric transported heavy metals based on national moss surveys. - Environ Monit. Assess. 43: 11-17.

[6] Borgna, L., Di Lella, L.A., Nannoni, F., Pisani, A., Pizzetti, E., Protano, G., Riccobono, F., Rossi, S. (2009): The high contents of lead in soils of northern Kosovo. - Journal of Geochemical Exploration 101: 137-146.

[7] ESC - Economic and Social Councile (2003): Results of heavy metals in mosse survey 200/2001. - United Nation EB.AIR/WG. 1/2003/8.

[8] Harmens, H., Norris, D. (2008): Spatial and temporal trends in heavy metal accumulation inProgramme mosses in Europe (1990-2005). - UNECE ICP Vegetation Coordination Centre. Centre for Ecology and Hydrology. Bangor, UK.

[9] Lepneva, O.M., Sluka, Z.A., Abramova, L.I. Obukov, A.I. (1987): Mosses as bioindicators of heavy metal pollution of the urban environment. - Nauchnye Doki Vyss Shkoly Biol Nauki 8: 87-91.

[10] Lippo, H., Poikolainen, J., Kubin, E. (1995): The use of moss. lichen and pine bark in the nationwide monitoring of atmospheric heavy metal deposition in Finland. - Water, Air and Soil Pollution 85: 2241-2246. 
[11] Loppi, S. (2004): Mapping the effects of air pollution. nitrogen deposition. agriculture and dust by the diversity of epipytic lichens in central Italy. - English Nature 525: 37-41.

[12] Markert, B.A., Breure, A.M., Zechmeister, H.G. (2003): Definitions. strategies and principles for bioindication/biomonitoring of the environment. - Trace Metals and other Contaminants in the Environment 6: 3-39.

[13] Mendil, D., Celik, F., Tuzen, M., Soylak, M. (2009): Assessment of trace metal levels in some moss and lichen samples collected from near the motorway in Turkey. - Journal of Hazardous Material 166: 1344-1350.

[14] Munzi, S., Raverab, S., Canevaa, G., (2007): Epiphytic lichens as indicators of environmental quality in Rome. - Environmental Pollution Volume 146: 350-358.

[15] Murati, M. (1991): Flora Lišajeva. - Universitet u Prishtini. Prishtina.

[16] Murati, M. (1993): Flora Lišajeva. - Skopje.

[17] Nylander, W. (1866): Les lichenes du Jardin du Lixemburg. - Bull. Soc. Bot Tidskr Fr 13: 364-372.

[18] Onianwa, P.C. (2001): Monitoring atmospheric metal pollution: A review of the use of mosses as indicators. - Environmental Monitoring and Assessment 71. 13-50.

[19] Pacyna, J.M., Pacyna, E.G. (2001): An assessment of global and regional emissions of trace metals to the atmosphere from anthropogenic sources wordwide. - Environmental Reviews 9: 269-298.

[20] Pejćinović, D., Hoxha, E. (1986): Liśajevi kao indikatori stepena zagađenosti živote sredine. - Natyra e Kosovës.

[21] Pejçinoviç, D., Murati, M., Hoxha, E. (1988): Uticaj oneciscenog vazduhana razvoj lisajeva u prodrucju Mitrovice. - Ohrid: IV Kongres Ekologa Jugoslavije.

[22] Pitcairn, C.E.R., Fowler, D., Grace, J. (1995): Deposition of fixed atmospheric nitrogen and foliar nitrogen content of bryophytes and Calluna vulgaris (L.) Hull. - Environmental Pollution 88: 193-205.

[23] Rühling, A. (1994): Atmospheric heavy metal deposition in Europe - estimations based on moss analyses. - NORD 9: 1-53.

[24] Seaward, M., Coppins, B.J. (2004): Lichens and hypertrophication. - Bibliotheca Lichenologica 88: 561-572.

[25] Sommerfeldt, M., Volker, J. (2001): Evaluation of a method for the Reassessment of air quality by Lichen Mapping in the City of Izmir, Turkey. - Turk J. Bot. 25: 45-55.

[26] Varjoranta, R., Pietarila, H. (2005): Dispersion of exhaust gases from Kosovo B power plant in Obiliq. - Finish meteorolgical institute air quality expert services. Helsinki.

[27] Whelpdale, D.M., Summers, P.W., Sanhueza, E. (1998): A global overview of atmospheric acid deposition fluxes. - Environmental Monitoring and Assessment 48: 217-247.

[28] WHO \& UNEP (1992): Urban Air Pollution in Megacities of the World. - Blackwell. London.

[29] Wirth, V. (1995): The Lichens - (English translation by Doyle Anderegg). BadenWürttemberg, 2 edition.

[30] Wolterbeek, H.T,. Kuik, P., Verburg, T.G., Herpin, U., Markert, B., Thöni, L. (1995): Moss interspecies comparisons in trace element concentrations. - Environmental Monitoring and Assessment 35: 263-286.

[31] World Health Organization (2002): Helath Action in Kosovo. - Newsletter on emergency prepardnessand response.

[32] Zechmeister, G., Grodzińska, K., Szarek-Łukaszewska, G. (2003): Bryophytes. - Trace Metals and other Contaminants in the Environment 6: 329-375. 